\title{
Revisiting the Salinity Tolerance of Crapemyrtles (Lagerstroemia spp.)
}

\author{
Raul I. Cabrera
}

\begin{abstract}
The crapemyrtle (Lagerstroemia L.) is one of the most popular flowering trees in the U.S. and abroad. L. indica cultivars have dominated urban and landscape settings until their recent displacement by modern interspecific $L$. indica $\times$ L. fauriei Kohene hybrids. This study evaluated the salt tolerance of an older $L$. indica cultivar, 'Pink Lace,' and the hybrids 'Natchez' and 'Basham's Party Pink.' While the growth of these three cultivars was significantly and negatively affected by increasing $\mathrm{NaCl}$ salinity (0 to $24 \mathrm{mM}$ ) in the irrigation water, the shoot to root ratio (S/R) and aesthetic parameters (chlorophyll content and salt burn ratings) of 'Pink Lace' was the most affected. This cultivar showed the most responsive relationships between salt burn ratings and sodium $(\mathrm{Na})$ and chloride $(\mathrm{Cl})$ accumulation in leaf tissues. 'Basham's Party Pink' was rated as the most salt tolerant, with relatively steady S/R, chlorophyll contents and salt burn rating across all salinities, and its leaf tissues had the lowest accumulation of $\mathrm{Na}$ and $\mathrm{Cl}$. Results from this study also support the hypothesis that geographical and ecological origins of the parent Lagerstroemia species and selections largely influences the relative salinity tolerance of the cultivars.

Key Words. Irrigation; Salinity Tolerance; Water Quality.
\end{abstract}

The woody ornamental crapemyrtle (Lagerstroemia), native to Southeast Asia, has been a favorite landscape plant and a staple nursery crop for the southern U.S. since the late 1700s (Egolf and Andrick 1978; Byers 1997; Dirr 1998). Selections and cultivars of the common crapemyrtle ( $L$. indica $L$.) have been the most widely used, favored for their colorful summer flowering and wide assortment of inflorescence colors and plant sizes (Egolf and Andrick 1978). The relatively recent introduction of interspecific hybrids of L. indica, native of China (Egolf and Andrick 1978; Dirr 1998), and L. fauriei Kohene, endemic only to the Japanese island of Yakushima (Egolf and Andrick 1978; Byers, 1997), have significantly enhanced crapemyrtle versatility by enhancing its cold hardiness, variety of growth habits, exfoliating bark and resistance to powdery mildew and certain species of beetles (Egolf and Andrick 1978; Byers 1997; Cabrera 2004; Hagan et al. 1998; Cabrera et al. 2008).

The common crapemyrtle (L. indica) has been recently named the official shrub for Texas (Cabrera 2004), a state in which water quantity and quality are serious and pervasive issues affecting its nursery and landscape industries. While the literature suggests that crapemyrtles are a salt-sensitive species (Francois 1982; Cabrera and Devereaux 1998), the only formal salinity study that included this genus did it only with a single L. indica selection (nonnamed cultivar) growing in a sandy loam soil (Francois 1982). The present study was conducted to obtain preliminary information regarding the tolerance of representative modern crapemyrtles cultivars, growing under production conditions, to increasing levels of salt stress in the irrigation water.

\section{MATERIALS AND METHODS}

Rooted cuttings, growing in $5 \mathrm{~cm}$ ( 2 in) square pots, of three crapemyrtle cultivars $-L$ indica 'Pink Lace' and the $L$. indica $\times$ fauriei hybrids 'Natchez' and 'Basham's Party Pink' - were used in the present study. 'Pink Lace' is an old cultivar, selected in 1957 in North Texas, and has been used extensively as a pistillate parent in the crapemyrtle breeding program at the U.S. National Arboretum (Egolf and Andrick 1978). The white-flowered hybrid 'Natchez,' introduced by the U.S. National Arboretum in 1978, is known for its fast growth rate and outstanding exfoliating bark, and is considered the most widely planted hybrid cultivar (Byers 1997; Dirr 1998). On the other hand, 'Basham's Party Pink' has the distinction of being the first known $L$. indica $\times$ faurie hybrid, originating as a chance seedling identified and selected in 1963 in Houston, TX (Byers 1997; Egolf and Andrick 1978).

The cuttings were transplanted on June 7, into \#4 [13 L (3.4 gal)] containers filled with a peat: pine bark: sand (2:1:1 $\mathrm{v} / \mathrm{v})$ medium amended with $3.0 \mathrm{~kg} / \mathrm{m}^{3}\left(5 \mathrm{lbs} / \mathrm{yd}^{3}\right)$ of dolomitic limestone and $0.6 \mathrm{~kg} / \mathrm{m}^{3}\left(1 \mathrm{lb} / \mathrm{yd}^{3}\right)$ of both the micronutrient fertilizer Micromax ${ }^{\circledR}$ (Scotts Co., Marysville, $\mathrm{OH}$ ) and the wetting agent Aquagro ${ }^{\circledR}$ 2000G (Aquatrols, Paulsboro, $\mathrm{NJ}$ ). Following transplant, the containers were top-dressed with $5.0 \mathrm{~kg} / \mathrm{m}^{3}\left(8.4 \mathrm{lbs} / \mathrm{yd}^{3}\right)$ of the controlled-release fertilizer Woodace 20-4-11 (Vigoro Industries, Fairview Heights, IL).

The containerized plants were placed in gravel beds lined with weed barrier fabric. There were a total of 6 replications (plants) per each treatment (cultivar $\times$ salt level) arranged in a completely randomized block design. The treatment plants were arranged in rows of three abreast, spaced at $30 \mathrm{~cm}$ (12 in) on centers, surrounded by rows of border (nontreatment) plants on the outsides. The plants were irrigated for 15-weeks (June 29-October 10) with tap water $[\mathrm{pH}=7.4$; electrical conductivity $(\mathrm{E})]=0.5 \mathrm{dS}$ $\mathrm{m}^{-1}$ (mmhos/cm); $73 \mathrm{ppm}$ alkalinity] salinized with $\mathrm{NaCl}$ salt at concentrations of $0,3,6,12$, and $24 \mathrm{mM}$ (equivalent to irrigation solution ECs of $0.5,0.8,1.1,1.7$, and $2.9 \mathrm{dS} \mathrm{m}^{-1}$, respectively-including the EC of the tap water). The plants were irrigated on average 2-4 times per week by pumping solutions from $100 \mathrm{~L}$ (26.4 gal) tanks, and delivered through individual 
calibrated Spot-Spitters ${ }^{\circledR}$ (Roberts Irrigation Products Inc., San Marcos, CA) located in each container. Reference evapotranspiration (ET) was determined gravimetrically in selected plants, and used to estimate irrigation volumes to apply. Sufficient solution was applied to produce a target leaching fraction of $30 \%$. Leachates were collected at discrete times over the experimental period in three plants per cultivar $\times$ salt level combination, and analyzed for $\mathrm{pH}$, electrical conductivity (EC) and Chloride (Cl) concentration (according to Adriano and Doner 1982).

From October 10-15, the plants were evaluated for growth (height, width) and leaf chlorophyll index (SPAD 502, Minolta, Japan). Plant growth index was calculated as the sum of plant height plus width 1 , plus perpendicular width 2 , and the total divided by 3 . In addition, plant salt burn ratings were subjectively assessed by two judges, using a scale of 0 to 5 ( $0=$ no salt damage, $5=$ salt burn damage on all leaves). Thereafter the plants were destructively harvested, separated by organs (stems, leaves, and roots) and dried at $70^{\circ} \mathrm{C}\left(158^{\circ} \mathrm{F}\right)$ until constant weight. Leaf tissues were ground to pass a 40-mesh screen and subjected to a full nutrient analysis (macro- and micronutrients), by using standard ICP spectroscopy procedures (conducted at the Soil Testing and Plant Analysis Laboratory of Louisiana State University, Baton Rouge, LA). Leaf Cl concentrations were determined according to Gilliam (1971).

Plant yield and quality responses to treatments were analyzed by ANOVA and regression procedures using SAS software (version 9.1, SAS Institute, Cary, NC). For regression procedures, the dry weights and growth index data were converted to relative values, which allowed the evaluation of the cultivars responses to salt treatment without the confounding effect of the absolute dry weight and growth differences inherent to each cultivar. This was accomplished by identifying the plant with the highest dry mass within each cultivar (across all salt treatments) and assigning it a value of 100 , which was then used to calculate the relative value for the rest of the plants within that cultivar.

\section{RESULTS AND DISCUSSION}

The addition of $\mathrm{NaCl}$ salt concentrations higher than $6 \mathrm{mM}$ to the irrigation water produced average leachate $\mathrm{EC}$ and $\mathrm{Cl}$ concentrations in excess of $2.5 \mathrm{dS} / \mathrm{m}^{1}$ (mmhos/cm) and $20 \mathrm{mM}(710$ $\mathrm{ppm}$ ), respectively (Figure 1). These values, representative of those being experienced by the roots, have been reported to significantly and negatively affect the growth of ornamental trees and large shrubs like Arbutus unedo (strawberry tree), Abelia grandiflora (glossy abelia), Cotoneaster congestus (Pyrenees cotoneaster), Mahonia aquifolium (Oregon grape holly), Liriodendron tulipifera (tulip tree); Feijoia sellowiana (pineapple guava), as well as an unnamed Lagerstroemia indica (common crapemyrtle) cultivar (Francois and Clark 1978; Francois 1982).

Before presenting the salinity response data of the evaluated cultivars, it should be noted that throughout the study it was readily apparent, the inherent vigor of the two interspecific hybrids 'Natchez' and 'Basham's Party Pink' visibly dominated over the biomass and growth responses of 'Pink Lace.' In southern U.S. landscapes, 'Pink Lace' is considered a "medium" grower (Egolf and Andrick 1978), reaching mature heights of 3-4.5 m (10-15 ft), contrasting to the 6-9 m (20-30 ft) mature heights of 'Natchez' and 'Basham's Party Pink' (Egolf and Andrick 1978; Byers 1997; Dirr 1998). Within the two interspecific hy-

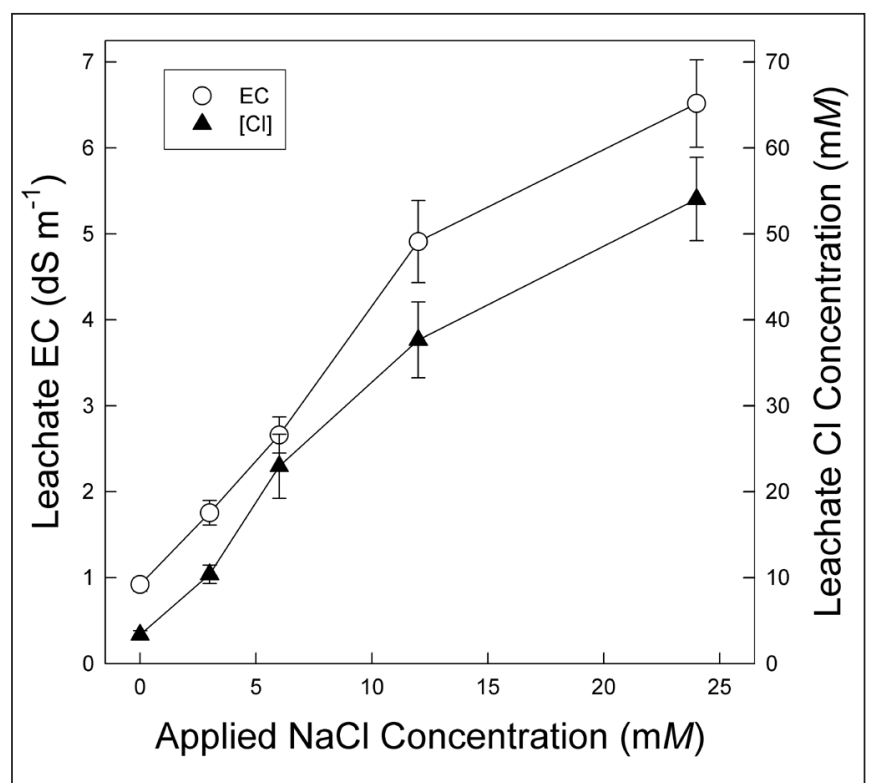

Figure 1. Average electrical conductivity (EC) and chloride concentration (C) in leachates collected from containerized plants of three crapemyrtle (Lagerstroemia) cultivars irrigated with increasing levels of $\mathrm{NaCl}$ salinity. Data points are means \pm standard errors of 27 leachate samples.

brids the 'Natchez' plants had higher leaf areas, total dry weights and growth indices, but 'Basham's Party Pink' had the highest root dry weights and lower shoot to root ratios (data not shown). It should be noted that 'Basham's Party Pink' can reach larger heights and widths than 'Natchez' on the milder parts of the southern United States and Gulf of Mexico regions, namely USDA Hardiness Zone 9a, but whose growth and performance significantly declines in colder zones (Byers 1997), commonly freezing to the ground. The present study was conducted in Dallas, TX, which is classified as a colder Hardiness Zone 8a.

If actual plant biomass and growth measurements are used, all the measured response variables show an interaction of cultivar selection and salinity levels (data not shown), with inherently large growth differences likely masking the relative response of the cultivars to increasing salt stress. Therefore, with the objective of having a better assessment of the relative salinity tolerance of the crapemyrtle cultivars without involving their geneticallydetermined growth differences, the use of relative values for dry weight and plant growth response variables was considered as a suitable method. This comparative approach was based on the classical evaluation of relative yield responses of field (agronomic and horticultural) crops to increasing salinity conditions (Maas 1990).

The interactive effects of cultivar by salt concentration observed when using actual values (data not shown) were effectively lost for total plant dry weight, leaf area and top dry weights when these were expressed on a relative basis (Figure 2, Table 1), and the plants from all three cultivars responded indistinctively, and negatively, to the salinity main effect. While Figure 2a shows only relative total plant dry weight as a function of salt stress, relative leaf area and relative top dry weights (not shown) were similar in their response. Interestingly, while relative root dry weight (Figure $2 b$ ) and relative plant growth index (Figure 2d) also responded negatively to the increasing 
Table 1. Equations of regressions lines fitted to relative plant growth and quality responses, and their relationships with leaf Na and $\mathrm{Cl}$ concentrations, in three crapemyrtle (Lagerstroemia) cultivars subjected to increasing $\mathrm{NaCl}$ stress. Data used in the regression procedures are presented in Figure 2 and Figure 3.

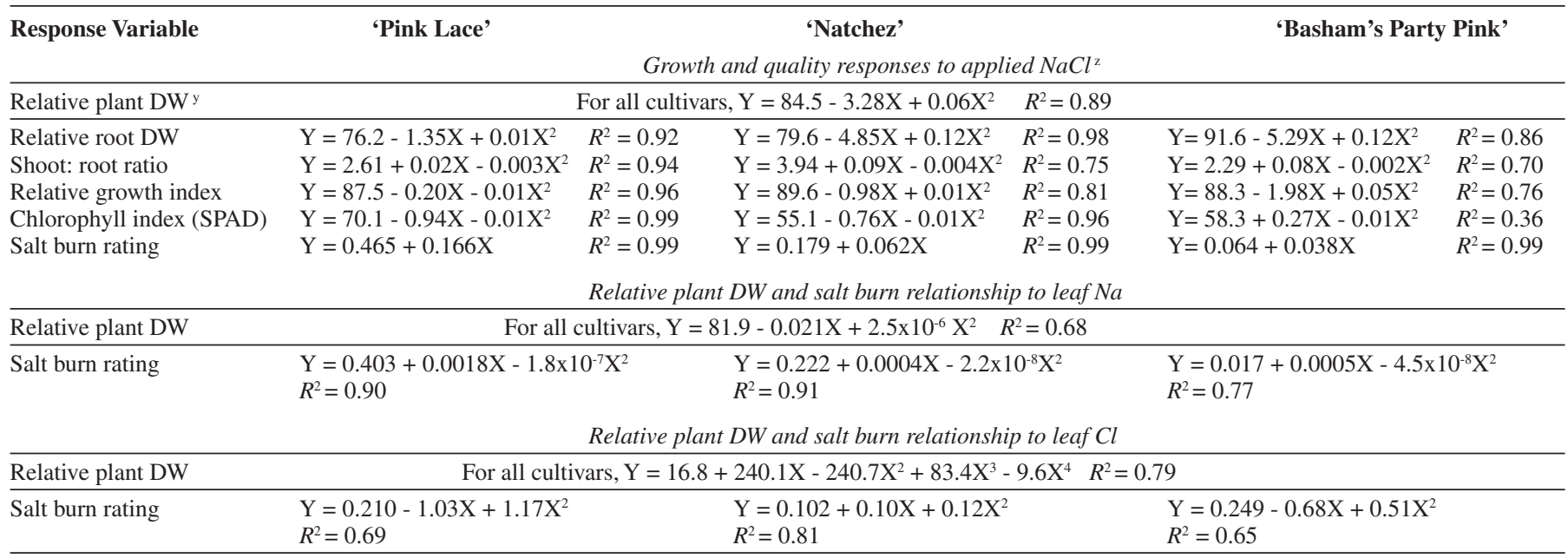

${ }^{\mathrm{z}}$ For equations: Y corresponds to the listed response (dependent) variable, while $\mathrm{X}$ denotes applied $\mathrm{NaCl}$ concentration or Leaf Na or $\mathrm{Cl}$ concentration (independent variables).

${ }^{y} \mathrm{DW}=$ Dry weight.

salinity conditions, the rate at which these parameters were reduced in the smaller 'Pink Lace' cultivar was less steep than in the larger 'Natchez' and 'Basham's Party Pink' cultivars.

The vigorous shoot (top) growth of 'Natchez' resulted in the generation of the largest average shoot to root ratio (S/R) across salinity levels, almost twice as large as that found in 'Pink Lace,' which incidentally was also the only cultivar showing the most visible decreases in $\mathrm{S} / \mathrm{R}$ with increasing salt stress (Figure 2c). While the S/R of 'Basham's Party Pink' were similar to those of 'Pink Lace' at the lowest salt concentrations $(<6 \mathrm{mM})$, they actually showed a slightly increasing trend at higher salt concentrations. These overall results indicate that despite the absolute and relative reduction in total plant dry weight with salinity stress observed in all cultivars (Figure 2a), the relative growth of the tops (shoots) in 'Pink Lace' decreased more than in its roots under increasing salinity, whereas those (S/R) ratios in 'Natchez' and 'Basham's Party Pink' tended to maintain an homeostatic equilibrium (Kozlowski et al. 1991; Harris et al. 1999). This observation suggests a relatively higher degree of physiological adjustment and/or tolerance to salinity in these two latter hybrid cultivars.

The overall foliage quality and plant aesthetics of the three crapemyrtles cultivars responded differentially to the increasing salinity stress. While overall leaf chlorophyll index (SPAD) readings decreased with salinity stress, these were largely confined to 'Pink Lace' and 'Natchez' (Figure 2e), which showed similar rates of reduction (i.e., slope) despite their noticeable difference in foliage, "greenness" ('Pink Lace' plants were significantly greener). Interestingly, the chlorophyll index of the 'Basham's Party Pink' plants barely changed across the salinity range, with a slight downward slope (in the fitted regression) observed only at the highest $\mathrm{NaCl}(24 \mathrm{~m} M)$ concentration. This observation is remarkable, as leaf chlorophyll content in woody ornamentals is reduced markedly under salt stress, even in those species regarded as salt tolerant (Percival 2005). It has been reported that low to moderate $\mathrm{NaCl}$ salinity stimulates chlorophyll degradation whereas higher salt concentrations more drastically affect chlorophyll synthesis (Santos 2004), and both physiological mechanisms conduce to reduced chlorophyll content and fluorescence (photosynthetic activity) (Santos 2004; Percival, 2005).

Foliage salt burn, expressed as scorching and necrosis in leaves and subjectively assessed on a 0 to 5 scale, showed that while these symptoms increased linearly with salinity stress (Figure 2f), they occurred at a steeper rate in 'Pink Lace' plants than in the hybrids. Plants of 'Basham's Party Pink' actually had the least foliage salt burn damage, and only the plants receiving the highest salt concentration $(24 \mathrm{mM})$ could be considered aesthetically unpleasant.

Regarding plant nutrient status, interactive effects between cultivar and salinity stress were only observed for leaf nitrogen $(\mathrm{N})$, phosphorous $(\mathrm{P})$, calcium $(\mathrm{Ca})$, sodium $(\mathrm{Na})$ and chloride (Table 2). Across all salinity concentrations cultivar selection had a highly significant effect on plant nutrient profile, with 'Basham's Party Pink' having the lowest leaf concentrations for all essential nutrients, albeit all of them were within the normal or sufficiency ranges reported in the literature for crapemyrtle cultivars and hybrids (Mills and Jones 1996; Cabrera and Devereaux 1998; Cabrera and Devereaux 1999).

As expected, leaf $\mathrm{Na}$ and $\mathrm{Cl}$ concentrations increased with salinity stress (Table 2), but the degree of accumulation was significantly influenced by the cultivar, with 'Basham's Party Pink' plants having the lowest concentrations. The literature rarely reports a range of $\mathrm{Cl}$ or $\mathrm{Na}$ levels considered adequate or optimum for tree growth and quality, but rather, and often, implies that they should be avoided whenever possible. This perception certainly contrasts with the categorization of $\mathrm{Cl}$ and $\mathrm{Na}$ as, respectively, essential and beneficial plant mineral nutrients (Marschner 1995).

In an effort to identify the range of $\mathrm{Na}$ and $\mathrm{Cl}$ concentrations (or accumulation) associated with acceptable crapemyrtle growth and quality, these values were correlated with their respective relative plant dry weights and salt burn ratings (Figure 3). The regression analysis showed that increasing leaf $\mathrm{Na}$ concentrations were associated with rather fast depressions in the growth of all cultivars (Figure 3a). Conversely, and interest- 
ingly, relative crapemyrtle dry weight yields showed increases with leaf tissue $\mathrm{Cl}$ concentrations up to $1.0 \%(10,000 \mathrm{ppm})$ but were significantly depressed at higher concentrations (Figure $3 b$ ). The lattermost observation is remarkable in that it suggests the 'optimum' range for crapemyrtle leaf $\mathrm{Cl}$ concentration puts it effectively in the macronutrient concentration range. While it has been reported that most salt sensitive woody species, like fruit trees, present toxicity symptoms when leaf $\mathrm{Cl}$ exceeds $0.35 \%$ (3500 ppm; Marschner 1995), some tree species, like kiwifruit (Actinidia deliciosa), have high $\mathrm{Cl}$ requirements with established leaf $\mathrm{Cl}$ critical concentrations of about 2.0\% (20,000 ppm; Smith et al. 1987).

Correlations of leaf $\mathrm{Na}$ and $\mathrm{Cl}$ with salt burn ratings revealed differential relationships between cultivars, with 'Pink Lace' plants showing the steeper and quickest responses (i.e., slopes). Leaf $\mathrm{Na}$ concentrations above $300 \mathrm{mg} / \mathrm{kg}^{-1}$ (ppm) were associated with rapidly increasing salt burn ratings in 'Pink Lace' but concentrations above $2,000 \mathrm{mg} / \mathrm{kg}^{-1}$ (ppm) were needed to produce unsatisfactory ratings in the hybrid cultivars (Figure 3c). On the other hand, and similar to plant dry weight response to tissue $\mathrm{Cl}$ accumulation, unsatisfactory salt burn ratings and plant appearance were observed when leaf $\mathrm{Cl}$ exceeded the $1.0 \%(10,000 \mathrm{ppm})$ mark (Figure 3d). Once again, a steeper

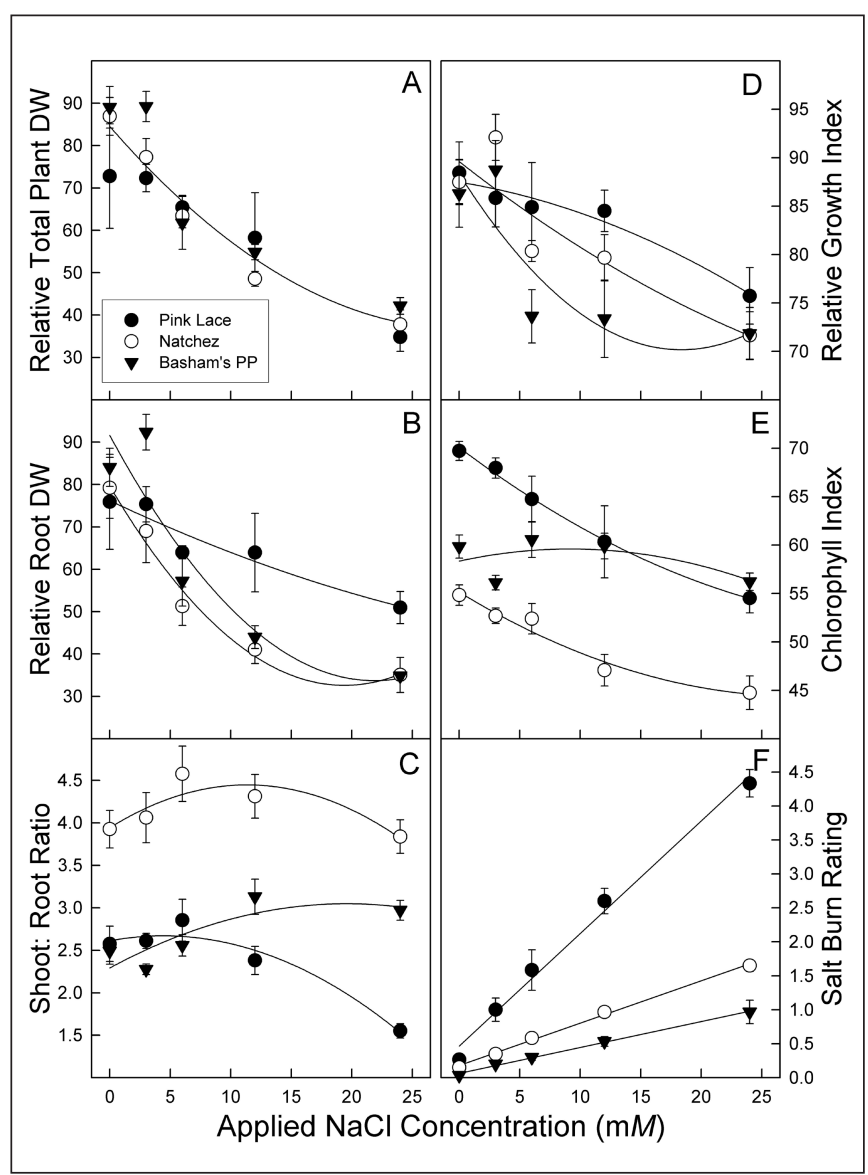

Figure 2. Relative total (A) and root (B) dry weights, shoot to root ratio (C), relative growth index (D), leaf chlorophyll (SPAD) index (E) and foliage salt burn ratings $(F)$ of three crapemyrtle (Lagerstroemia) cultivars irrigated with increasing levels of $\mathrm{NaCl}$ salinity. Data points are means \pm standard errors of 6 plants. The parameters for the fitted regression lines are shown in Table 2. relationship between leaf $\mathrm{Cl}$ and salt burn was noted for 'Pink Lace' plants and was minimal in 'Basham's Party Pink' plants.

Overall result analysis indicates that while on the basis of plant biomass (growth) determinants, modern cultivars of the genus Lagestroemia could certainly retain a categorization of salt-sensitive; aesthetically they have a broader range of tolerance to salinity. While further evaluation is needed in a broader range of crapemyrtle cultivars, the data from the present study and that of Francois (1982), suggests that cultivars of the common crapemyrtle ( $L$. indica) are less tolerant of salt stress than the modern interspecific hybrids (L. indica $\times$ fauriei) being widely used by the landscape industry today.

From an ecophysiological perspective, it is contended the continental origin of $L$. indica, attributed to mainland China (Egolf and Andrick 1978), would have evolutionarily provided less exposure of this species to the salinity stress experienced by an island species like the Japanese L. fauriei (Egolf and Andrick 1978; Byers 1997). Under the premise that natural selection has resulted in developing salt tolerant species, and ecotypes within species, researchers have logically expected best salinity tolerance results when using progeny of plants growing in increasingly saline environments (Nicknam and McComb 2000). It is assumed the relatively higher salt tolerance of hybrids 'Natchez' and 'Basham's Party Pink' observed in the present study was inherited from the Japanese parent. It should be noted that 'Basham's Party Pink' was a chance seedling identified and selected in the coastal city of Houston, TX (Egolf and Andrick 1978). The results from the present study pointing 'Basham's Party Pink' as effectively the most salt tolerant cultivar, with the more steady (less changing) shoot to root ratios, leaf chlorophyll indices and salt burn ratings (Figure 2c, Figure 2e, Figure $2 \mathrm{f}$ ) and lowest accumulation of $\mathrm{Na}$ and $\mathrm{Cl}$ in leaf tissues (Figure 3c, Figure 3d), supports the contention that island and/or coastal regions would result in the selection of plant materials with higher salinity tolerance. While this selection strategy has been commonly used, the expectation however that these starting materials will show higher degrees of salinity tolerance has not always been met (Allen et al. 1994; Nicknam and McComb 2000). To effectively test this hypothesis in crapemyrtles, it will be necessary to comparatively evaluate the salinity tolerance of a larger number of cultivars representing these and other Lagerstroemia species and their interspecific hybrids, an effort that is currently underway.

\section{LITERATURE CITED}

Adriano, D.C., and H.E. Doner. 1982. Bromine, chlorine, and flourine, pp. 460-461. In: A.L. Page, R.H. Miller, and D.R. Keeney (Eds). Methods of Soil Analysis, Part 2. American Society of Agronomy, Inc. and Soil Science Society of America, Inc. Madison, WI.

Allen, J.A., J.L. Chambers, and D. McKinney. 1994. Intraspecific variation in the response of Taxodium distichum seedlings to salinity. Forest Ecology and Management 70:203-214.

Byers, D. 1997. Crapemyrtle: A Grower's Thoughts. Owl Bay Publishers, Inc. Auburn, AL.

Cabrera, R.I. 2004. Evaluating and promoting the cosmopolitan and multipurpose Lagerstroemia. Acta Horticulturae 630:177-184.

Cabrera, R.I., and D.R. Devereaux. 1998. Effects of nitrogen supply on growth and plant nutrient status of containerized crapemyrtle. Journal of Environmental Horticulture 16:98-104. 
Table 2. Concentration of selected minerals in leaves of three crapemyrtle (Lagerstroemia) cultivars subjected to increasing salinity stress. The plants were subjected to the salinity treatments over a 15 week experimental period.

\begin{tabular}{|c|c|c|c|c|c|c|c|c|c|}
\hline \multirow[b]{2}{*}{ Independent Variable } & $\mathrm{N}^{\mathrm{z}}$ & $\mathrm{P}$ & $\mathrm{K}$ & $\mathrm{Ca}$ & $\mathrm{Mg}$ & $\mathrm{Fe}$ & $\mathrm{Mn}$ & $\mathrm{Na}$ & $\mathrm{Cl}$ \\
\hline & & & \multicolumn{3}{|l|}{$(\%)$} & \multicolumn{3}{|c|}{$\left(\mathrm{mg} \mathrm{kg}^{-1}\right)$} & $(\%)$ \\
\hline \multicolumn{10}{|l|}{$\overline{\text { Cultivar }^{y}}$} \\
\hline 'Pink Lace' & $2.70 \mathrm{a}$ & $0.23 \mathrm{a}$ & $1.34 \mathrm{~b}$ & $2.42 \mathrm{a}$ & $0.63 \mathrm{~b}$ & $119 \mathrm{a}$ & 566 a & $1368 \mathrm{~b}$ & $1.60 \mathrm{~b}$ \\
\hline 'Natchez' & $2.41 \mathrm{~b}$ & $0.25 \mathrm{a}$ & $1.51 \mathrm{a}$ & $1.73 \mathrm{~b}$ & $0.68 \mathrm{a}$ & $110 \mathrm{~b}$ & 549 a & $1770 \mathrm{a}$ & $1.77 \mathrm{a}$ \\
\hline 'Basham's Party Pink' & --- & $0.19 \mathrm{~b}$ & $1.17 \mathrm{c}$ & $1.70 \mathrm{~b}$ & $0.53 \mathrm{c}$ & $103 \mathrm{~b}$ & 506 a & $1155 \mathrm{~b}$ & $1.39 \mathrm{c}$ \\
\hline \multicolumn{10}{|l|}{$\mathrm{NaCl}$ Concentration } \\
\hline $0 \mathrm{~m} M$ & 2.50 & 0.21 & 1.28 & 2.03 & 0.63 & 102 & 520 & 179 & 0.63 \\
\hline $6 \mathrm{~m} M$ & 2.48 & 0.22 & 1.36 & 2.01 & 0.62 & 116 & 511 & 479 & 1.61 \\
\hline $12 \mathrm{~m} M$ & 2.56 & 0.23 & 1.36 & 1.97 & 0.61 & 118 & 620 & 1921 & 2.19 \\
\hline $24 \mathrm{~m} M$ & 2.76 & 0.25 & 1.35 & 1.79 & 0.57 & 117 & 532 & 4283 & 2.23 \\
\hline \multicolumn{10}{|l|}{ ANOVA $^{x}$} \\
\hline Cultivar (CV) & $* * *$ & $* * *$ & $* * *$ & $* * *$ & $* * *$ & $* *$ & NS & $* *$ & $* * *$ \\
\hline Salt Concentration (SC) & $*$ & $* * *$ & NS & NS & $*$ & $* *$ & NS & $* * *$ & $* * *$ \\
\hline $\mathrm{CV} * \mathrm{SC}$ & $* *$ & $*$ & NS & $* *$ & NS & NS & NS & $* *$ & $* * *$ \\
\hline
\end{tabular}

${ }^{\mathrm{z}}$ Leaf $\mathrm{N}$ concentration data was only available for two cultivars, and thus statistical analysis of data for this element applies only to those two cultivars.

y Mean separation of cultivar main effects by Duncan's LSD (0.05). Mean values having similar letters are not significantly different from each other.

${ }^{x}$ Analysis of variance for main effects $(\mathrm{CV}, \mathrm{SC})$ and interaction $(\mathrm{CV} * \mathrm{SC})$. NS $=$ not significantly different; *,**, and $* * *$ indicate significance at $P \leq 0.05, P \leq 0.01$, and $P \leq 0.001$, respectively.

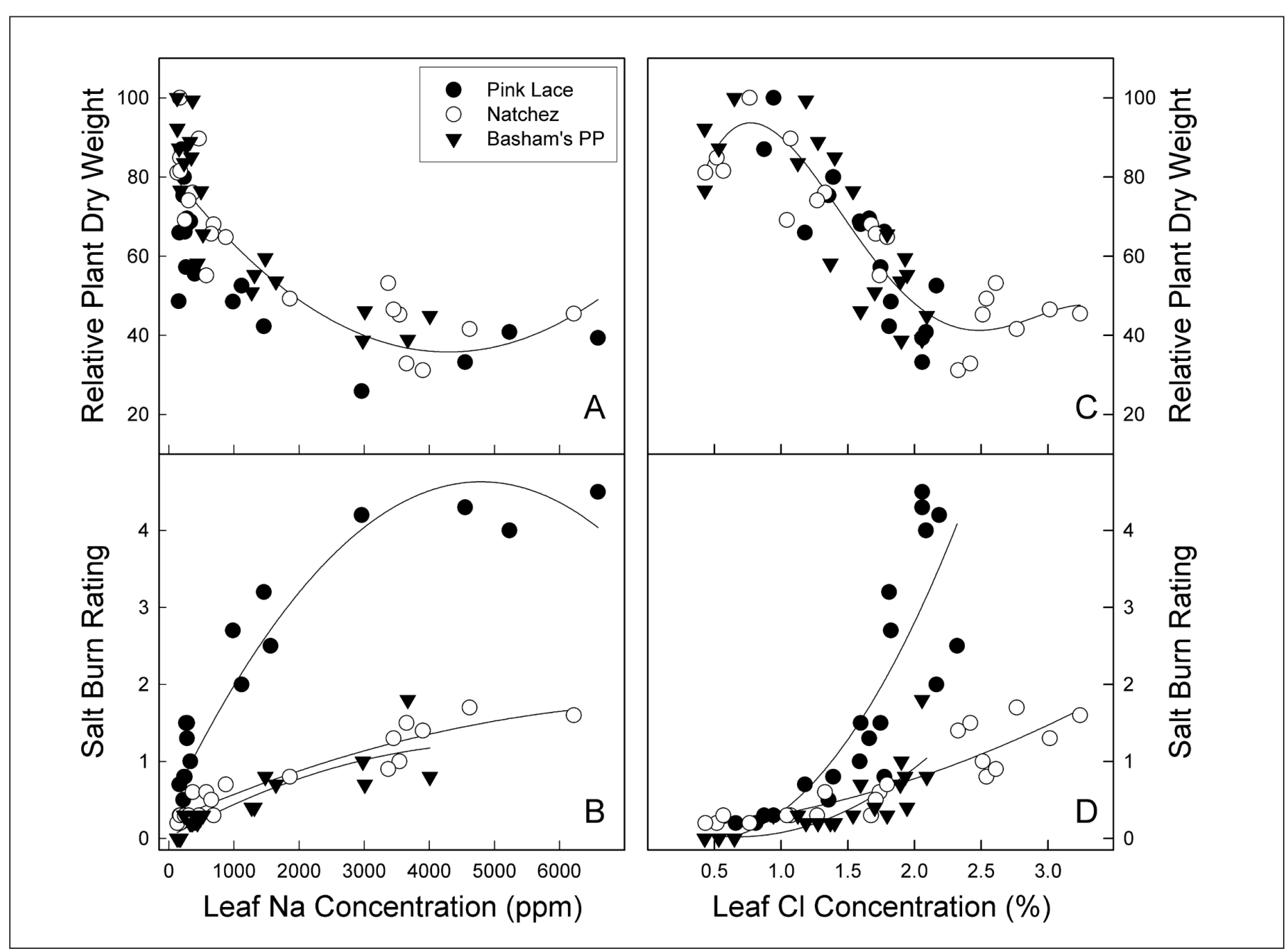

Figure 3. Relationships between relative whole plant dry weights (A, C) and foliage salt burn ratings (B, D) and leaf sodium and chloride concentrations in three crapemyrtle (Lagerstroemia) cultivars irrigated with increasing levels of $\mathrm{NaCl}$ salinity. Each data point represents a single plant. The parameters for the fitted regression lines are shown in Table 2. 
Cabrera, R.I., and D. R. Devereaux. 1999. Crapemyrtle post-transplant growth as affected by nitrogen nutrition during nursery production. Journal of the American Society for Horticultural Science 124:94-98.

Cabrera, R.I., J.A. Reinert and C.B. Mckenney. 2008. Differential resistance among crapemyrtle (Lagerstroemia) species, hybrids and cultivars to foliar feeding by adult flea beetles (Altica litigata). HortScience 43:286-583.

Dirr, M.A. 1998. Manual of Woody Landscape Plants, 5th Edition. Stipes Publishing. Champaign, IL. 187 pp.

Egolf, D.R., and A.O. Andrick. 1978. The Lagerstroemia Handbook/ Checklist. American Society of Botanical Gardens and Arboreta, Inc.

Francois L.E. 1982. Salt tolerance of eight ornamental tree species. Journal of the American Society for Horticultural Science 107:66-68.

Francois L.E., and R.A. Clark. 1978. Salt tolerance of ornamental shrubs, trees and iceplant. Journal of the American Society for Horticultural Science 103:280-283.

Gilliam, J.W. 1971. Rapid measurement of chlorine in plant materials. Soil Science Society of America Proceedings 35:512-513.

Hagan, A.K, G.J. Keever, C.H. Gilliam, J.D. Williams, and G. Creech. 1998. Susceptibility of crapemyrtle cultivars to powdery mildew and Cercospora leaf spot in Alabama. Journal of Environmental Horticulture 16:143-147.

Harris, R.W., J.R. Clark, and N.P. Matheny. 1999. Arboriculture: Integrated Management of Landscape Trees, Shrubs, and Vines. 3rd Ed. Prentice Hall, Upper Saddle River, NJ. 687 pp.

Kozlowski, T.T., P.J. Kramer, and S.G. Pallardy. 1991. The Physiological Ecology of Woody Plants. Academic Press. San Diego. 657 pp.

Maas, E.V. 1990. Crop salt tolerance, pp. 262-304. In: K.K. Tanji (Ed). Agricultural Salinity Assessment and Management. American Society of Civil Engineers (ASCE), Manuals and Reports on Engineering No. 71. New York, NY.

Marschner, H. 1995. Mineral Nutrition of Higher Plants. 2nd Ed. Academic Press, San Diego, CA. 889 pp.

Mills, H.A., and J.B. Jones. 1996. Plant Analysis Handbook II. MicroMacro Publishing, Inc. Athens, GA. 422 pp.

Nicknam, S.R., and J. McComb. 2000. Salt tolerance screening of selected Australian woody species - a review. Forest Ecology and Management. 139:1-19.

Percival, G.C. 2005. Identification of foliar salt tolerance of woody perennials using chlorophyll fluorescence. HortScience 40:1892-1897.

Santos, C.V. 2004. Regulation of chlorophyll biosynthesis and degradation by salt stress in sunflower leaves. Scientia Horticulturae 103:93-99.

Smith, G.S., C. Clark, and P. Holland. 1987. Chloride requirements of kiwifruit (Actinidia deliciosa). New Phytologist 106:71-80.

Acknowledgments. This work was supported with funding provided by the Texas Nursery and Landscape Association, the Specialty Crop Research and Product Development Grant Program of the Texas Department of Agriculture, and the USDA-CSREES Rio Grande Basin Initiative (Agreements No. 2005-34461-15661 and No. 2005-45049-03209).

Raul I. Cabrera

Texas A\&M AgriLife Research and Extension Center

17360 Coit Road

Dallas, Texas 75252, U.S.

r-cabrera@tamu.edu
Résumé. Le Lagesrtroemia L. est l'un des arbres à fleurs les plus populaires aux États-Unis et ailleurs. Les cultivars de L. indica ont dominé le paysage urbain et paysager jusqu'à leur remplacement récent par les hybrides modernes de $L$. indica $\times$ L. fauriei Kohene. Cette étude évalue la tolérance au sel d'un vieux cultivar de L. indica, 'Pink Lace', et des hybrides 'Natchez' et 'Basham's Party Pink'. Alors que la croissance de ces trois cultivars était significativement et négativement affectée par l'augmentation de la salinité en $\mathrm{NaCl}(0$ à $24 \mathrm{mM}$ ) dans le système d'irrigation, les paramètres de ratio pousse sur racine (S/R) et esthétiques (contenu chlorophyllien et degré de brûlure par le sel) de 'Pink Lace' étaient les plus affectés. Ce cultivar a présenté la plus grande réponse relationnelle entre les degrés de brûlure par le sel et les accumulations en sodium $(\mathrm{Na})$ et en chlorure $(\mathrm{Cl})$ dans les tissus foliaires. 'Basham's Party Pink' était le plus tolérant au sel avec des valeurs de S/R, de contenu en chlorophylle et des degrés en brûlure par le sel relativement stables à tous les taux de salinité; il avait également la plus faible accumulation en $\mathrm{Na}$ et en $\mathrm{Cl}$ dans les tissus foliaires. Les résultats de cette étude supportent également l'hypothèse que les origines géographiques et écologiques des parents des espèces de Lagerstroemia et de leur sélections influencent largement la tolérance à la salinité des divers cultivars.

Zusammenfassung. Die Lagerstömie (Lagerstroemia L.)ist eine der beliebtesten Blütenpflanzen in den USA und anderswo. Kultivare der $L$. indica dominierten die urbane Landschaftsgestaltung, bis sie kürzlich durch die moderne Neuzüchtung. indica $\times$ L. fauriei Kohene ersetzt wurden. Diese Studie bewertet die Salztoleranz eines älteren $L$. indicaKultivars (Pink Lace) und der Hybriden Natchez und Bashams Party Pink. Während das Wachstum dieser drei Kultivare deutlich negativ durch die zunehmende Versalzung der Böden durch Bewässerung beeinflusst wurde, wurden das Trieb-Wurzel-Verhältnis und die ästhetischen Parameter (Chlorophyllgehalt und Salzverbrennung) von Pink Lace besonders stark beeinflusst. Dieser Kultivar zeigte den größten Einfluss von NaCLAkkumulation in den Blattgeweben auf die Rate an Salzverbrennungen. Bashams Party Pink war sehr salztolerant und seine Blätter hatten die geringste NaCl-Akkumulation. Die Ergebnisse dieser Studie unterstützen die Hypothese, dass die geographische und ökologische Herkunft der Lagerstroemia-Arten und Selektionen einen großen Einfluss auf die Salztoleranz der Kultivare hat.

Resumen. La astronómica (Lagerstroemia L.) es uno de los árboles de flor más populares en los Estados Unidos y en el extranjero. Los cultivares de $L$. indica han dominado los paisajes urbanos hasta su reciente desplazamiento por los modernos interespecíficos híbridos $L$. indica $\times$ L. fauriei Kohene. Este estudio evaluó la tolerancia a la sal del cultivar L. indica, 'Pink Lace' y los híbridos 'Natchez' y 'Basham's Party Pink'. Mientras que el crecimiento de estos tres cultivares fue significativa y negativamente afectado por el incremento de la salinidad con $\mathrm{NaCl}(0$ a $24 \mathrm{mM}$ ) y el riego, la relación brote raíz (S/R) y parámetros estéticos (contenido de clorofila y quemaduras por sal) de 'Pink Lace' fueron los más afectados. Este cultivar mostró las relaciones más efectivas entre quemaduras por sal y acumulación de sodio $(\mathrm{Na})$ y cloruro $(\mathrm{Cl})$ en los tejidos foliares. 'Basham's Party Pink' fue evaluado como el más tolerante a la sal, con $\mathrm{S} / \mathrm{R}$ relativamente estables, contenidos de clorofila y quemaduras por sal en todas las salinidades, y sus tejidos tuvieron la acumulación más baja de $\mathrm{Na} \mathrm{y} \mathrm{Cl}$. Los resultados de este estudio también suportan la hipótesis de que los orígenes geográficos y ecológicos de las especies y selecciones parentales de Lagerstroemia influyen en la tolerancia relativa a la salinidad de los cultivares. 